\title{
Ammonium and Glutamate Released by Neurons Are Signals Regulating the Nutritive Function of a Glial Cell
}

\author{
Marcos Tsacopoulos, ${ }^{1,2}$ Carol L. Poitry-Yamate, ${ }^{1,2,3}$ and Serge Poitry ${ }^{1,2}$ \\ ${ }^{1}$ Experimental Ophthalmology Laboratory and Departments of ${ }^{2}$ Physiology and ${ }^{3}$ Pharmacology, University of Geneva \\ Medical School, 1211 Geneva 4, Switzerland
}

\begin{abstract}
Glial cells transform glucose to a fuel substrate taken up and used by neurons. In the honeybee retina, photoreceptor neurons consume both alanine supplied by glial cells and exogenous proline. Ammonium $\left(\mathrm{NH}_{4}{ }^{+}\right)$and glutamate, produced and released in a stimulus-dependent manner by photoreceptor neurons, contribute to the biosynthesis of alanine in glia. Here we report that $\mathrm{NH}_{4}{ }^{+}$and glutamate are transported into glia and that a transient rise in the intraglial concentration of $\mathrm{NH}_{4}{ }^{+}$or of glutamate causes a net increase in the level of reduced nicotinamide adenine dinucleotides $[\mathrm{NAD}(\mathrm{P}) \mathrm{H}]$. Biochemical measurements indicate that this is attributable to activation of glycolysis in glial cells by the
\end{abstract}

direct action of $\mathrm{NH}_{4}{ }^{+}$and glutamate on at least two enzymatic reactions: those catalyzed by phosphofructokinase (PFK; ATP:D-fructose-6-phosphotransferase, EC 2.7.1.11) and glutamate dehydrogenase (GDH; L-glutamate:NAD oxidoreductase, deaminating; EC 1.4.1.3). This activation leads to an increase in the production and release of alanine by glia. This signaling, which depends on the rate of conversion of $\mathrm{NH}_{4}{ }^{+}$and glutamate to alanine and $\alpha$-ketoglutarate, respectively, in the glial cells, raises the novel possibility of a tight regulation of the nutritive function of glia.

Key words: $\mathrm{NADH}$; $\mathrm{pH}$; fluorescence imaging; $\mathrm{NH}_{4}{ }^{+}$transport; glutamate transport; retina
Growing evidence suggests that astrocytes, by their physiological interactions with neurons, are involved in mammalian brain function and energy metabolism (Pellerin and Magistretti, 1994). However, the complex structural interactions among astrocytes, neurons, and capillaries make functional quantitation difficult at the cellular level. Although cultured astrocytes have provided a basis for understanding brain energy metabolism, there is presently no clear reported case in which a molecular signal physiologically released from neurons actually exerts a fine control of glial metabolism. Glutamate, a major excitatory neurotransmitter in the CNS, is a case in point. Extensive electrophysiological work on acutely isolated vertebrate glia has demonstrated that glutamate is taken up electrogenically by glia (Brew and Attwell, 1987). In cultured astrocytes, this uptake activates glucose uptake and metabolism, and it has been suggested that this activation is attributable to increased activity of a glial-specific $\mathrm{Na}^{+} / \mathrm{K}^{+}$ ATPase (Pellerin and Magistretti, 1994). However, alternative possibilities can be evoked. First, because the enzyme converting glutamate to glutamine at the expense of ammonia and ATP apparently is localized exclusively in glia, it is expected that an increased glutamate uptake into astrocytes would lead to a decrease in intracellular levels of ATP and ammonia. The question remains whether this decrease constitutes a primary metabolic signal and whether these levels are restored in astrocytes by increasing oxidative metabolism and ammonia uptake. Second, glutamate uptake causes the $\mathrm{pH}$ in glial Müller cells to go acid,

Received Sept. 24, 1996; revised Dec. 17, 1996; accepted Jan. 17, 1997.

This work was supported by Swiss National Science Foundation Grants 3139426.93 and 31-37587.93 and the Georges Kernen Foundation. We thank Drs. D. Attwell, J. A. Coles, and L. Pizurki for critical comments and Mr. P. Perrottet for expert technical assistance.

Correspondence should be addressed to Dr. C. L. Poitry-Yamate, Experimental Ophthalmology Laboratory, University of Geneva Medical School, 1 Rue MichelServet, 1211 Geneva 4, Switzerland.

Copyright (C) 1997 Society for Neuroscience $0270-6474 / 97 / 172383-08 \$ 05.00 / 0$ and it was suggested that this transient $\mathrm{pH}$ change may be a signal to alter glial metabolism (Bouvier et al., 1992). Thus, although glutamate affects the metabolic state of glia, whether it further constitutes a signal coupling neuron function and metabolism to those in glia only can be surmised. We approached the problem of metabolic signaling between neurons and glia in honeybee retina because direct analysis performed in this preparation already has proven to provide an unsurpassed basis for parallel studies in mammals (Poitry-Yamate et al., 1995).

The honeybee retina has been an appropriate model system for exploring metabolic interactions between neurons and glial cells, because light-sensitive photoreceptor neurons have almost all of the mitochondria, whereas glial cells are packed with glycogen. Moreover, although glial cells do not respond directly to light (Tsacopoulos et al., 1987; Coles, 1989), their glycogen metabolism is modified when photoreceptors are photo-stimulated (EvêquozMercier and Tsacopoulos, 1991). Furthermore, glia transform glucose to alanine, which, in turn, is taken up and used by photoreceptors (Tsacopoulos et al., 1994). By analogy in mammals, evidence indicates that astrocytes fuel neurons with lactate (Larrabee, 1983; Poitry-Yamate et al., 1995; Tsacopoulos and Magistretti, 1996). In honeybee retina, photoreceptors also consume proline (Tsacopoulos et al., 1994), and this consumption leads to the production and release, in a stimulus-dependent manner, of $\mathrm{NH}_{4}{ }^{+}$and glutamate, which, in turn, contribute to the biosynthesis of alanine in glia (Tsacopoulos et al., 1997). Here we show that ammonium $\left(\mathrm{NH}_{4}{ }^{+}\right)$and glutamate released by photoreceptors return to glial cells not simply for nitrogen conservation but as information signals.

\section{MATERIALS AND METHODS}

Materials. [U- ${ }^{14} \mathrm{C}$ ]glutamate was purchased from Amersham (Zürich, Switzerland; specific activity $266 \mathrm{mCi} / \mathrm{mmol}, 1 \mathrm{Ci}=37 \mathrm{GBq})$. $\left[\mathrm{U}-{ }^{14} \mathrm{C}\right]$ Glucose was purchased from DuPont/NEN (Boston, MA; specific activity $298 \mathrm{mCi} / \mathrm{mmol}$ ). 2,7-Biscarboxyethyl-5(6)-carboxyfluorescein-AM 
(BCECF-AM) was obtained from Molecular Probes (Leiden, The Netherlands). Other chemicals or enzymes have been used previously (Tsacopoulos et al., 1994; Veuthey et al., 1994) and were obtained from Sigma (Buchs, Switzerland), Fluka (Buchs, Switzerland), or Calbiochem (Basel, Switzerland).

Preparation of retinal homogenates and a mitochondrial fraction from drone retinal slices. For the measurement of ammonia, retinal slices, retinal homogenates, and the mitochondrial fraction were prepared as previously described in Tsacopoulos et al. (1987) and Veuthey et al. (1994). Briefly, nonretinal portions of a slice were removed by microdissection with fine forceps, leaving a pure retinal slice. Batches of retinal slices then were homogenized manually. Parts of these homogenates were processed further by subcellular fractionation (see Veuthey et al., 1994) for isolation of the mitochondrial fraction. $\mathrm{NH}_{4}^{+}$was assayed with dansyl-Cl (5-dimethylamino-1-naphthalene-sulfonyl chloride) derivatization in sodium borate buffer $(164 \mathrm{~mm}, \mathrm{pH} 10.0)$ and reverse-phase HPLC (Tsacopoulos et al., 1994). As a control, rat brain slices were homogenized and assayed with the same procedure.

Preparation of glial cells isolated from drone retina. For biochemical experiments, preparations of glial cells still attached to the basal membrane were used. Briefly, slices of retina, prepared as previously described (Coles, 1989), were pinned onto a SYLGARD support and the brain matter carefully removed without mechanically disrupting the basal membrane. Then the tissue was exposed to continuously oxygenated Trisbuffered Ringer's solution (in mM): $\mathrm{NaCl} 270, \mathrm{KCl} 10, \mathrm{CaCl}_{2} 1.6, \mathrm{MgCl}_{2}$ 10 , and Tris(hydroxymethyl)-aminomethane $10, \mathrm{pH} 7.1$, containing 5 $\mathrm{mg} / \mathrm{ml}$ of Pronase (Ref 53702 from Calbiochem) for $20 \mathrm{~min}$ at room temperature. The cornea was removed at this stage, and the two retinas per slice were transferred for washing to a Falcon tube that was rocked on its side for $10 \mathrm{~min}$. Then the tissue was exposed to a $0 \mathrm{Ca}^{2+} / 0 \mathrm{Mg}^{2+}$ Ringer's solution containing (in $\mathrm{mM}$ ): $\mathrm{NaCl} 200, \mathrm{KCl} 10$, EDTA 1, MOPS 10 , and sucrose $240, \mathrm{pH} 6.9$ [at this stage and at all later stages, the osmolarity of Ringer's solution was raised with sucrose to match that of extracellular fluid, deduced as $630 \mathrm{mOsm} / \mathrm{kg}$ by Cardinaud et al. (1994)] With $8-15 \mathrm{mg} / \mathrm{ml}$ of trypsin (Sigma; trypsin was dialyzed to avoid contamination by $\mathrm{NH}_{4}^{+}$) added, the contents then were vortexed at low speed for $5 \mathrm{~min}$. This disrupted the glial syncytium (Tsacopoulos et al., 1987, 1994; Coles, 1989), releasing and destroying the majority of photoreceptors. It left an intact preparation of glial cells still attached to the basal membrane, and it also released some isolated glial cells (singlets or in bundles). In the preparation of glial cells attached to the basal membrane, succinate dehydrogenase activity (succinate oxidoreductase; EC 1.3.99.1) was exceedingly small; hexokinase activity (ATP:D-hexose-6phosphotransferase; EC 2.7.1.1) was conserved, and cell metabolism was similar to that found in glia of intact retinas (Evêquoz-Mercier and Tsacopoulos, 1991; Tsacopoulos et al., 1994). Both preparations of glia (attached or unattached to the basal membrane) were washed in a Ringer's solution of the following composition (in $\mathrm{mM}$ ): $\mathrm{NaCl} 200, \mathrm{KCl}$ $10, \mathrm{CaCl}_{2} 2, \mathrm{MgCl}_{2} 4.5$, MOPS 10, sucrose 200, and trehalose 40, $\mathrm{pH}$ 6.9; unless otherwise indicated, this was the standard Ringer's solution used for experiments. Singlets or bundles of glial cells freed during the procedure were used for fluorescence imaging experiments. These cells were attached to glass coverslips coated with poly-L-lysine and left in the standard Ringer's solution $3-12 \mathrm{hr}$ at $\sim 8^{\circ} \mathrm{C}$, before fluorescence imaging. In $\sim 20 \%$ of the overall glial preparations used for $\mathrm{NAD}(\mathrm{P}) \mathrm{H}$ fluorescence imaging, puffs of either glutamate or $\mathrm{NH}_{4} \mathrm{Cl}$ had a negligible or considerably delayed effect. Despite apparent morphological integrity of the preparations, these responses occurred on a given day and so may reflect metabolic alterations of cells consequent to the dissociation procedure.

Fluorescence imaging of individual glial cells. Fluorescence was measured at room temperature on an inverted Axiovert 135TV epifluorescence microscope equipped with Zeiss Pan-Neofluar $63 \times$ oil immersion lens [1.25 numerical aperture (NA)] and fit with a xenon arc lamp, neutral density filters, and an electromagnetic shutter. Selected cells were positioned in the middle of the optical field, and the focal plane was centered on the cells, the surfaces of which were attached to the coverslip. Injection pipettes (tip diameter $\sim 4 \mu \mathrm{m}$ ) were advanced from both sides to just above the central portion of the preparation and remained in place for the duration of the entire protocol. Images were captured every $2 \mathrm{sec}$ with a CCD (charged-coupled device) camera (Photonic Science, Robertsbridge, UK) and processed by IonVision software (ImproVision, Coventry, UK) on a Power Macintosh $8100 / 100 A$ V computer. Sequences of raw images were played as film before analysis and quantitation to exclude cell movement. For NAD(P)H fluorescence, excitation was at $380 \mathrm{~nm}$, and light emitted near $470 \mathrm{~nm}$ was collected. Fluorescence intensities were expressed in arbitrary pixel units. For $\mathrm{pH}_{\mathrm{i}}$ measurements, cells were exposed for $30 \mathrm{~min}$ to the fluorescent dye BCECF-AM $(5 \mathrm{mg} / \mathrm{ml})$. After washout of extracellular dye, $\mathrm{pH}_{\mathrm{i}}$ was measured from the ratio of light emitted near $550 \mathrm{~nm}$ on excitation at 490 and $440 \mathrm{~nm}$ after background substraction, as described (Bouvier et al., 1992).

$\left[U-{ }^{14} \mathrm{C}\right]$ glutamate uptake, ${ }^{14} \mathrm{C}$-alanine production from $\left[\mathrm{U}_{-}{ }^{14} \mathrm{C}\right]$ glucose and $\left[\mathrm{NH}_{4}^{+}\right]$. In experiments designed to determine the sodium dependence of glutamate uptake, freshly isolated preparations of glial cells attached to the basal membrane were washed in either normal (i.e., $\mathrm{Na}^{+}$-containing) or $\mathrm{Na}^{+}$-free (choline replacing $\mathrm{Na}^{+}$) standard Ringer's solution for $15 \mathrm{~min}$ before transfer to closed incubation microwells at room temperature. Four preparations per incubation were used. ${ }^{14} \mathrm{C}(\mathrm{U})$ Glutamate was used at a concentration of $50 \mu \mathrm{M}$ for the times indicated in sodium- or choline-containing Ringer's solution (total bath volume, $100 \mu \mathrm{l})$. Afterward, the bath was pipetted and the cells washed of adhering ${ }^{14} \mathrm{C}(\mathrm{U})$-glutamate, and both were stored in liquid nitrogen before HPLC analysis. During the protein assay, the basal membrane was separated from the glial cells.

In experiments involving the production of ${ }^{14} \mathrm{C}$-alanine from ${ }^{14} \mathrm{C}(\mathrm{U})$ glucose, glial cells (still attached to the basal membrane) from two retinas were incubated in standard Ringer's solution (no trehalose) carrying the indicated amounts of ${ }^{14} \mathrm{C}(\mathrm{U})$-glucose for $60 \mathrm{~min}$ in the presence of $\mathrm{NH}_{4}{ }^{+}$ plus glutamate $\left(1 \mathrm{mM}\right.$ each) or $\mathrm{NH}_{4}{ }^{+}$alone $(1 \mathrm{mM})$. In controls, no glutamate or $\mathrm{NH}_{4}^{+}$was added. For the determination of alanine and of glutamate inside the glial cells and in the corresponding bath, the preparation indicated as "fresh" in Figure 3 was exposed to proline (150 mM) during the final wash before being frozen in liquid nitrogen. Analysis of amino acids was performed with reverse-phase chromatography coupled to precolumn derivatization with orthophthaldehyde and fluorescence detection (HP 1090 HPLC system, Hewlett-Packard, Palo Alto, CA) (Tsacopoulos et al., 1994; Poitry-Yamate et al., 1995).

\section{RESULTS}

\section{Ammonia transport and signaling}

Ammonia essentially is produced in the mitochondria of photoreceptors (Fig. 1, left) and subsequently is released into the extracellular space (Tsacopoulos and Poitry, 1995; Coles et al., 1996a; Tsacopoulos et al., 1997). Previously, we showed that light stimulation of honeybee retinal slices or exposure to dinitrophenol (both induce an increase in the $\mathrm{O}_{2}$ consumption of photoreceptors; Tsacopoulos et al., 1987) causes an increased release of $\mathrm{NH}_{4}{ }^{+}$into the extracellular space. Recent measurements with $\mathrm{NH}_{4}{ }^{+}$- and $\mathrm{pH}$-sensitive microelectrodes showed that photoreceptors, within seconds of an increase in their oxidative metabolism, release an increased amount of $\mathrm{NH}_{4}{ }^{+} / \mathrm{NH}_{3}$, which, in turn, induces an increase of $\mathrm{pH}$ in the interstitial cleft and $\mathrm{NH}_{4}{ }^{+} / \mathrm{NH}_{3}$ entry into presumably glial cells (Coles et al., 1996a). In keeping with these results, we observed that the intraglial pool of $\mathrm{NH}_{4}{ }^{+}$ varies with the level of $\mathrm{NH}_{4}{ }^{+}$in the extracellular space (Fig. $1 a$, right). In addition, when glial cells $3-8 \mathrm{hr}$ after isolation were puffed with $\mathrm{NH}_{4} \mathrm{Cl}, \mathrm{pH}_{\mathrm{i}}$ became acid (Fig. 1e), indicating that either $\mathrm{NH}_{4}{ }^{+}$, rather than $\mathrm{NH}_{3}$, entered the cells (Kikeri et al., 1989; Coles et al., 1996a) or that glycolysis was activated. This acidification was smaller than that measured under similar conditions after a longer $(2 \mathrm{~min})$ exposure of the cells to $2 \mathrm{mM} \mathrm{NH}_{4}{ }^{+}$ (Coles et al., 1996b). As shown in Figure 1b,c, puffs of $\mathrm{NH}_{4} \mathrm{Cl}$ at the glial surface caused up to a $100 \%$ increase in the fluorescence of reduced nicotinamide adenine dinucleotides [i.e., NADH and/or NADPH, abbreviated in this text as $\mathrm{NAD}(\mathrm{P}) \mathrm{H}]$. Exposure to $8 \mathrm{mM} \mathrm{BaCl}_{2}$ from the bath reversibly suppressed this effect (Fig. 1c). Suppression also was observed on cell exposure to $\mathrm{Na}^{+}$-free (Fig. $2 b$ ) or to $\mathrm{Cl}^{-}$-free solution (Fig. 1d), consistent with a strong decrease of the $\mathrm{NH}_{4}{ }^{+}$-induced transient acidosis (Fig. 1e). Thus, $\mathrm{NH}_{4}{ }^{+}$entry into these glial cells shares properties with that in kidney cells (Kinne et al., 1986; Kikeri et al., 1989; Amlal et al., 1994), suggesting that it also may be mediated by a Na${ }^{+} / \mathrm{K}^{+} / 2 \mathrm{Cl}^{-}$ 
$\boldsymbol{a}$

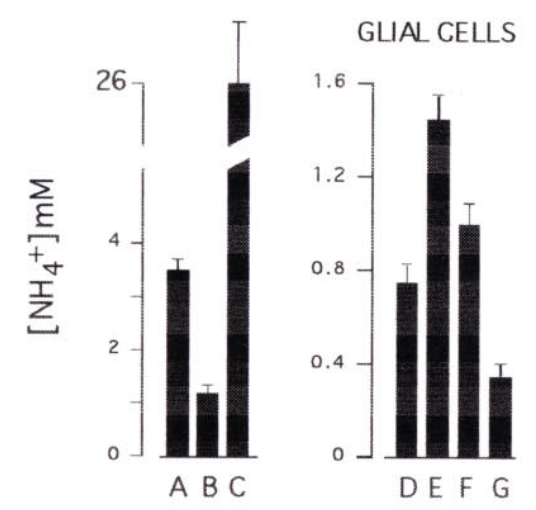

$c$

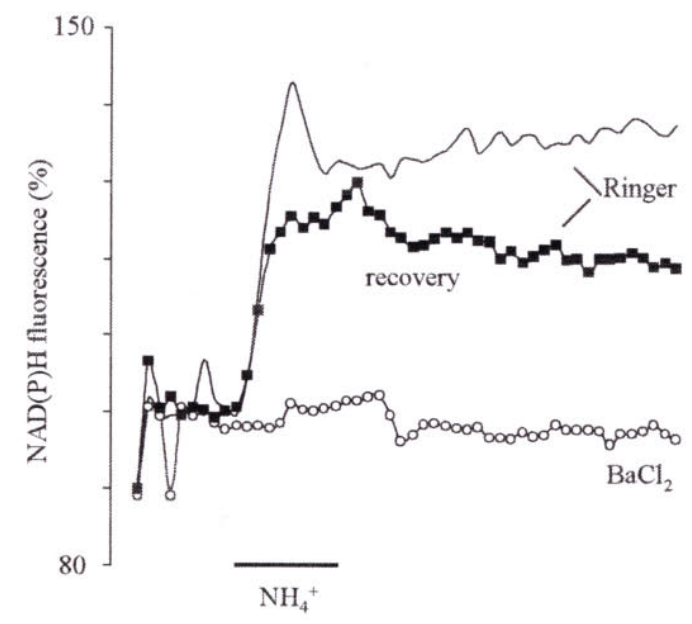

$b$
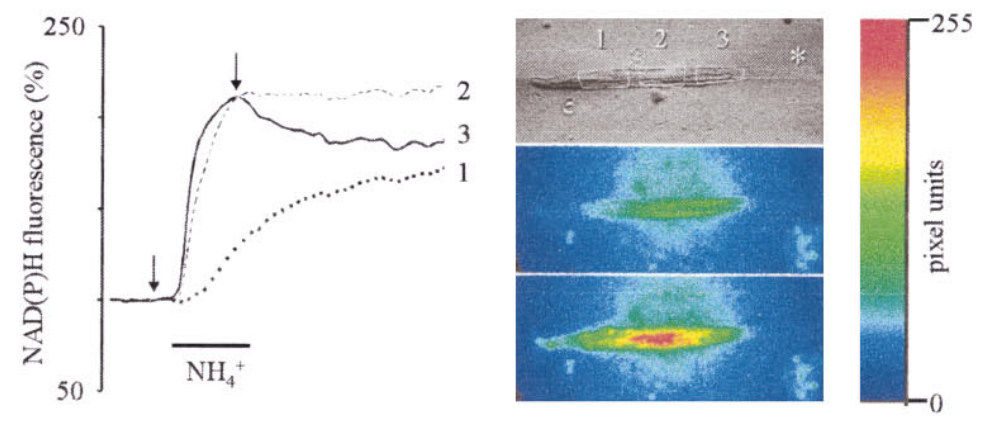

$d$

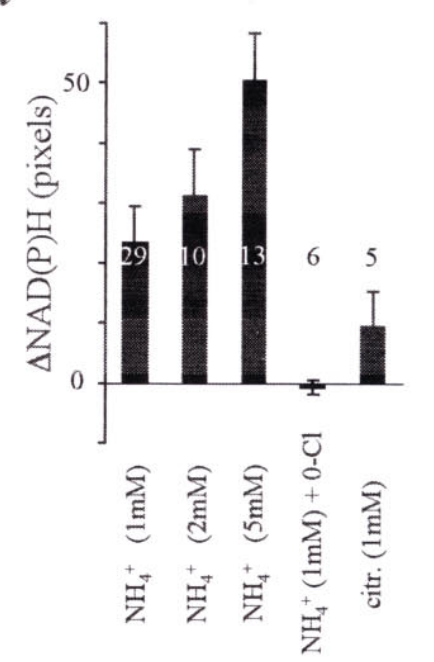

$e$

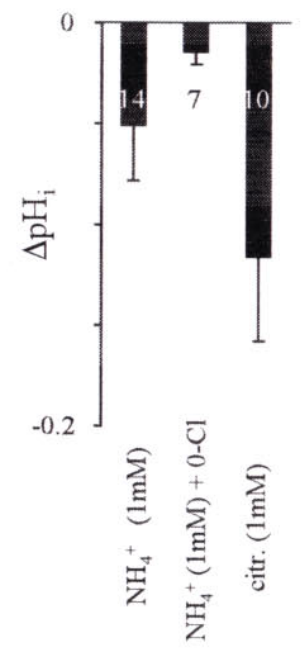

Figure 1. $\mathrm{NH}_{4}{ }^{+}$produced by oxidative metabolism in photoreceptors is taken up by glial cells, where it decreases pH $\mathrm{i}$ and increases $\mathrm{NAD}(\mathrm{P}) \mathrm{H}$. $a$, Left panel, $\left[\mathrm{NH}_{4}{ }^{+}\right]$in whole retinal slices and in subcellular compartments. $A$, Fresh slice, immediately frozen; $B$, retinal homogenate; $C$, mitochondrial fraction of retinal homogenate. Right panel, Dependence of $\left[\mathrm{NH}_{4}{ }^{+}\right]$in freshly isolated glial cells on incubating conditions. $D$, After $1 \mathrm{hr}$ in 0 -NH${ }_{4}^{+}$, Ringer's solution; $E$, after $1 \mathrm{hr}$ in $400 \mu \mathrm{M} \mathrm{NH}_{4}^{+} ; F, 1 / 2 \mathrm{hr}$ after returning to $0-\mathrm{NH}_{4}{ }^{+} ; G$, at $18 \mathrm{hr}$ after returning to $0-\mathrm{NH}_{4}{ }^{+}$. Values are mean $\pm \mathrm{SEM}(n=10)$. $b$, Left panel, Increase of $\mathrm{NAD}(\mathrm{P}) \mathrm{H}$ fluorescence in glial cells in response to puffing $\mathrm{NH}_{4} \mathrm{Cl}$; the increase was larger and faster near the puffer tip (traces 2 and 3). Puff duration, $20 \mathrm{sec}$. Arrows indicate times of capture of fluorescence images shown on right panel. Numbers 1-3 correspond to analyzed cell regions (right panel, top). Right panel, Bundle of five isolated glial cells (top) and image of their basal (middle) and peak (bottom) $\mathrm{NAD}(\mathrm{P}) \mathrm{H}$ fluorescence captured after $\mathrm{NH}_{4} \mathrm{Cl}$ puff. Pseudocolor scale of $\mathrm{NAD}(\mathrm{P}) \mathrm{H}$ fluorescence levels, with increases toward red. Asterisk overlies $\mathrm{NH}_{4} \mathrm{Cl}$ puffer. $c$, Exposure of glial cells to $\mathrm{BaCl}_{2}(8 \mathrm{mM})$ reversibly suppressed $\mathrm{NH}_{4} \mathrm{Cl}$-induced $\Delta \mathrm{NAD}(\mathrm{P}) \mathrm{H}$ response. $d, \mathrm{NH}_{4}{ }^{+}$at indicated concentrations, but not citrate, leads to significant $\mathrm{NAD}(\mathrm{P}) \mathrm{H}$ increases. $\mathrm{Cl}^{-}$-free Ringer's solution suppresses the effect of $\mathrm{NH}_{4}{ }^{+} . e, \mathrm{pH}_{\mathrm{i}}$ changes elicited by same substances as in $d$. Results in $d$ and $e$ are means of $n$ (superimposed on bars) measurements \pm SEM.

cotransporter and a barium-sensitive $\mathrm{K}^{+} / \mathrm{H}^{+}$exchanger. This uptake system allows the entry of $\mathrm{NH}_{4}{ }^{+}$into glia, but not its exit. Thus, the slow recovery of $\left[\mathrm{NH}_{4}{ }^{+}\right]$after a transient accumulation (Fig. 1a) probably reflects its chemical fixation in the process of alanine biosynthesis (see below). The extreme scarcity of mitochondria in drone glia (Tsacopoulos et al., 1987; Coles, 1989), as well as the relative homogeneity of the basal fluorescence along the cells (Fig. 1b, right), favors the idea that the measured fluorescence was cytosolic. It is, however, difficult to determine whether it was attributable to NADH or to NADPH, because the spectral properties of these compounds are almost identical. We suggest that the rapid rise of fluorescence in response to puffing $\mathrm{NH}_{4} \mathrm{Cl}$ reflected an increase in the $\mathrm{NADH}$ level consecutive to an activation of glycolysis by $\mathrm{NH}_{4}{ }^{+}$ions. We do not exclude that $\mathrm{NADH}$ in excess then was converted to NADPH, but this would require the presence of a transhydrogenase, which was not determined here. When the kinetics of intraglial $\Delta \mathrm{NAD}(\mathrm{P}) \mathrm{H}$ and $\Delta \mathrm{pH}$ in response to puffs of $\mathrm{NH}_{4} \mathrm{Cl}$ were compared, no clear differences were revealed in their rising phases. However, citrate caused a larger and longer-lasting acidification than $\mathrm{NH}_{4}{ }^{+}$but a correspondingly smaller change in $\mathrm{NAD}(\mathrm{P}) \mathrm{H}$ fluorescence (Fig. 1d,e). Hence, we suggest that transient increases in $\mathrm{NAD}(\mathrm{P}) \mathrm{H}$ levels are elicited by a direct, $\mathrm{pH}$-independent action of $\mathrm{NH}_{4}{ }^{+}$on a glycolytic enzyme. Phosphofructokinase (PFK; ATP:D-fructose-6phosphotransferase, EC 2.7.1.11) is a possible target because it has been shown in mammalian brain extracts that $\mathrm{NH}_{4}{ }^{+}$acts on it as an allosteric activator (Lowry and Passonneau, 1966). In agreement, activation of glycolysis in rat brains was reported when $\mathrm{NH}_{4}{ }^{+}$concentration in the blood was raised from 0.01 to $1.74 \mathrm{mM}$ (Hawkins et al., 1973). 
$\boldsymbol{a}$

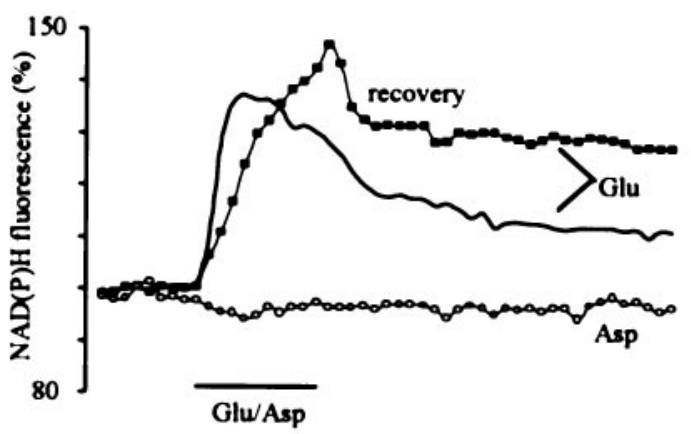

C

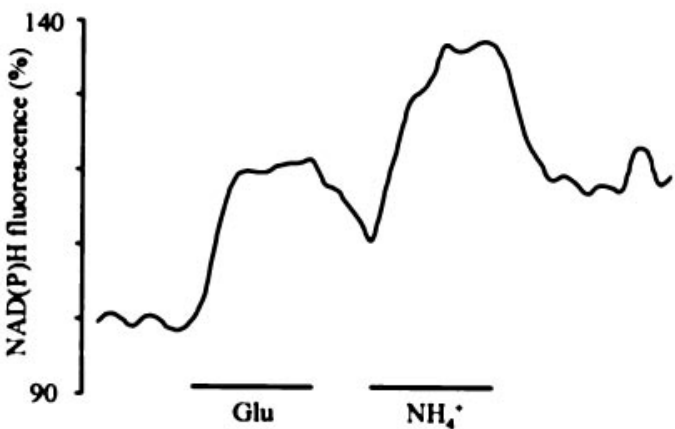

$\boldsymbol{d}$

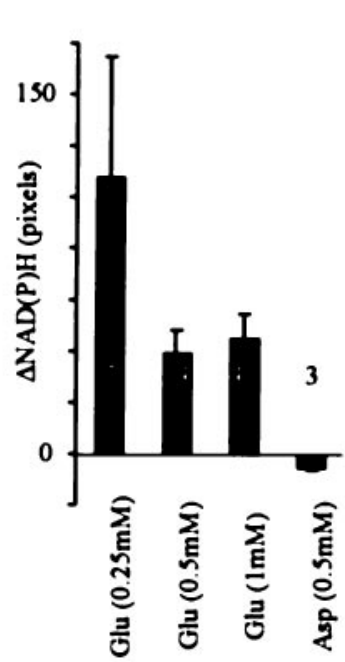

b
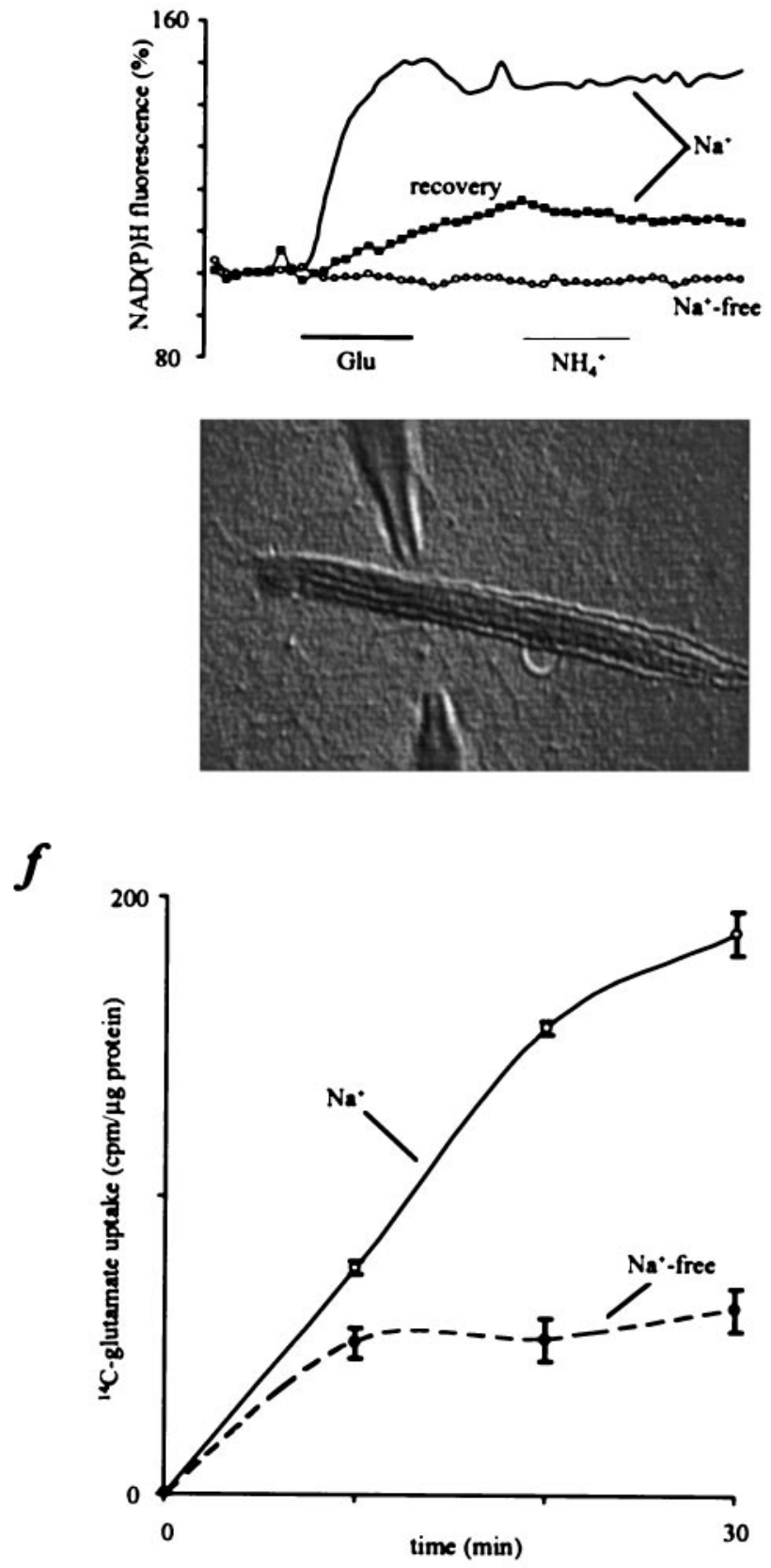

Figure 2. Glutamate induces in glial cells an increase of $\mathrm{NAD}(\mathrm{P}) \mathrm{H}$ fluorescence and a decrease of $\mathrm{pH}_{\mathrm{i}}$. $a$, A 20 sec puff of $0.5 \mathrm{~mm}$ glutamate $(G l u)$, but not of $0.5 \mathrm{~mm}$ aspartate $(A s p)$, induces $\mathrm{NAD}(\mathrm{P}) \mathrm{H}$ fluorescence increase. Puffing glutamate after aspartate (recovery) led to a slower rise in $\mathrm{NAD}(\mathrm{P}) \mathrm{H}$ fluorescence. $b$, Effect of glutamate $(1 \mathrm{mM})$ on $\mathrm{NAD}(\mathrm{P}) \mathrm{H}$ fluorescence was reversibly suppressed when $\mathrm{Na}^{+}$in the bath was replaced by equimolar amounts of choline. During choline exposure, puffing $\mathrm{NH}_{4} \mathrm{Cl}$ in choline-Ringer's solution (second time bar) had no effect on fluorescence. Response to glutamate partially recovered, 5 min after return to normal $\mathrm{Na}^{+}$(recovery). Lower panel, Bundle of four glial cells and tips of two puffers. $c$, Puffing $1 \mathrm{~mm}$ $\mathrm{NH}_{4} \mathrm{Cl}$ after $1 \mathrm{~mm}$ glutamate induces a further increase in $\mathrm{NAD}(\mathrm{P}) \mathrm{H}$ fluorescence. Puff duration in $a-c$ was 20 sec. $d$, Glutamate at three concentrations, but not aspartate, leads to significant $\mathrm{NAD}(\mathrm{P}) \mathrm{H}$ increases. $e$, Both glutamate and aspartate induce a significant, transient, intracellular acidosis in glial cells. Results in $d$ and $e$ are means of $n$ (superimposed on bars) measurements \pm SEM. $f$, Transport of radiolabeled [U- ${ }^{14} \mathrm{C}$ ]glutamate into glia is $\mathrm{Na}^{+}$-dependent. Cells were exposed to $50 \mu \mathrm{M}\left[\mathrm{U}_{-}{ }^{14} \mathrm{C}\right]$ glutamate for the times indicated, in either $\mathrm{Na}^{+}$or choline containing Ringer's solution. Each time point represents four separate experiments $(4 \times 4$ retinas $) \pm$ SEM.

\section{Glutamate transport and signaling}

There is strong evidence that glutamate production and its nonvesicular release in the synapse-free honeybee retina (Coles, 1989; Tsacopoulos et al., 1994) are predominantly neuronal. First, analysis of the retinal interstitial fluid in living honeybees showed that the concentration of glutamate there is 10 times higher than in the hemolymph (Cardinaud et al., 1994), indicating retinal production and release. Second, when the intact retina is exposed to $\left[{ }^{15} \mathrm{~N}\right]$ proline, which is consumed in the mitochondria of photoreceptors (Tsacopoulos et al., 1994), ${ }^{15} \mathrm{~N}$-glutamate is produced and rapidly 


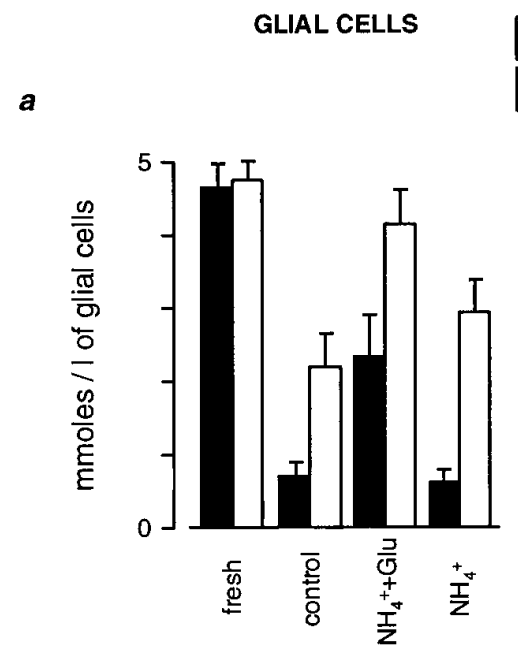

$$
\begin{aligned}
& \square \text { Ala } \\
& \text { Glu }
\end{aligned}
$$

$\boldsymbol{b}$

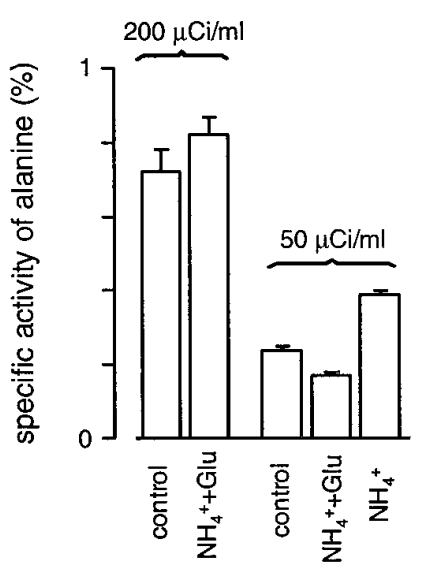

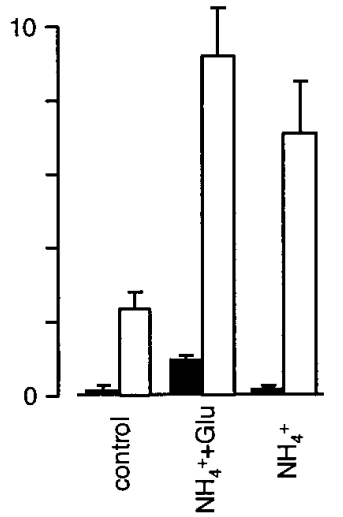

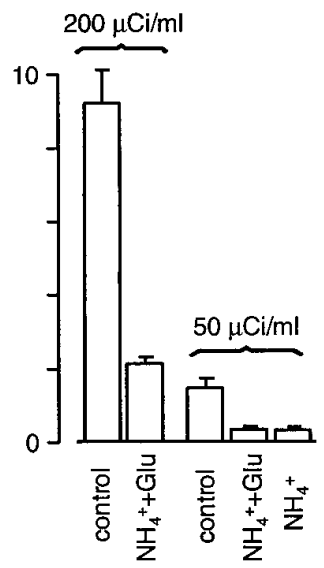

Figure 3. $\mathrm{NH}_{4}{ }^{+}$alone or $\mathrm{NH}_{4}{ }^{+}$plus glutamate causes an increase in alanine synthesis and release in glia. $a$, Amounts of alanine (Ala, open bars) and glutamate (Glu, filled bars) found in glial cells (left) and in the bathing solution (right); all values are expressed relative to cell volume. Intraglial concentrations of glutamate and alanine decrease when cells are maintained for $60 \mathrm{~min}$ in Ringer's solution. On addition of $\mathrm{NH}_{4}{ }^{+}$ $(1 \mathrm{~mm})$ or of glutamate and $\mathrm{NH}_{4}^{+}(1 \mathrm{~mm}$ each $)$, both [glutamate $]_{\mathrm{i}}$ and [alanine] $]_{\mathrm{i}}$ increased after $60 \mathrm{~min}$. The concentration of glutamate in glial cells was much higher than its actual concentration in the bath (bath volume $>100 \times$ cells volume), indicating very restricted release and probable accumulation. Glutamate plus $\mathrm{NH}_{4}^{+}$or $\mathrm{NH}_{4}^{+}$alone caused a significant increase ( $p<0.001$ and $p<0.02$, respectively) in the biosynthesis and release of alanine into the bath relative to control conditions. $b$, Specific radioactivity of alanine in the cells (left) and in the bath (right) after incubation for $60 \mathrm{~min}$ in Ringer's solution containing either of two $\left[\mathrm{U}_{-}{ }^{14} \mathrm{C}\right]$ glucose concentrations. In the cells, only $\mathrm{NH}_{4}{ }^{+}$alone had a significant $(p<0.02)$ effect on the specific radioactivity of alanine. Alanine was the only amino acid labeled from $\left[\mathrm{U}-{ }^{14} \mathrm{C}\right]$ glucose. All controls are pooled on the same column. Data are expressed as mean $\pm \operatorname{SEM}(n=9)$.

released into the extracellular space (Tsacopoulos et al., 1997). Third, freshly isolated glia do not produce and release extracellularly measurable amounts of glutamate (Fig. $3 a$, right), and $[\mathrm{glu}]_{\mathrm{i}}$ in isolated glial cells is $\sim 20$-fold lower (Fig. $3 a$, left) than that measured in retinal slices (Tsacopoulos et al., 1994). Fourth, using an enzyme-based glutamate-sensitive microelectrode (Innocent, 1995) positioned near the surface of freshly isolated honeybee photoreceptors (Tsacopoulos et al., 1994), we measured a glutamate concentration of 2-4 $\mu \mathrm{M}$ ( 3 cells), whereas it was virtually zero in the surrounding bath. These findings suggest that glial cells take up glutamate released by photoreceptors. Because the pro-

duction of alanine from glucose is coupled to the recycling of $\mathrm{NAD}(\mathrm{P})^{+}$via the activity of glutamate dehydrogenase $(\mathrm{GDH}$; L-glutamate:NAD oxidoreductase, deaminating; EC 1.4.1.3) in glial cells (Tsacopoulos et al., 1994; Veuthey et al., 1994) and because $\mathrm{NH}_{4}{ }^{+} / \mathrm{NH}_{3}$ feeds into this reaction consuming NAD(P)H (Fahien et al., 1971), we tested whether glutamate enters glial cells and modulates NAD(P)H. Puffing glutamate $(0.25-1 \mathrm{~mm})$ onto individual glial cells caused a net increase in $\mathrm{NAD}(\mathrm{P}) \mathrm{H}$ fluorescence (Fig. $2 a-d$ ), as would be expected if glycolysis were activated and GDH activity were decreased via product inhibition. Consistent with this hypothesis, when $\mathrm{NH}_{4}{ }^{+}$ was puffed $20 \mathrm{~s}$ after glutamate, $\mathrm{NAD}(\mathrm{P}) \mathrm{H}$ fluorescence increased further (Fig. 2c). The effect of glutamate on $\mathrm{NAD}(\mathrm{P}) \mathrm{H}$ was reversibly suppressed when $\mathrm{Na}^{+}$in the bathing solution was replaced by choline (Fig. $2 b$ ), indicating that glutamate enters glial cells through a high-affinity $\mathrm{Na}^{+}$-dependent glutamate transport system similar to that already described for vertebrate glial cells (Brew and Attwell, 1987). Furthermore, cell exposure for $\sim 40$ min to $1 \mathrm{~mm} \beta$-methyl-aspartate, an inhibitor of glutamate transporter (Kanai and Hediger, 1992), irreversibly suppressed the glutamate-induced $\triangle \mathrm{NAD}(\mathrm{P}) \mathrm{H}$ without significantly changing basal $\mathrm{NAD}(\mathrm{P}) \mathrm{H}$ fluorescence. To assess whether glutamate is deaminated oxidatively to $\alpha$-ketoglutarate as a consequence of product inhibition and $\mathrm{Na}^{+}$-dependent entry, we incubated bundles of glial cells with radiolabeled glutamate and followed its uptake and transformation over time (Fig. $2 f$ ). There was a rapid uptake of $\left[\mathrm{U}^{-14} \mathrm{C}\right]$ glutamate, and within $20 \mathrm{~min}$ the amount of $\left[\mathrm{U}-{ }^{14} \mathrm{C}\right]$ glutamate that had accumulated in the cells approached a plateau (Fig. $2 f$ ), in part because there was in parallel a production of ${ }^{14} \mathrm{C}$ - $\alpha$-ketoglutarate $(0.68 \pm 0.17 \mathrm{mmol} / 1$ of glia $/ \mathrm{min} ; n=$ 16 cell batches), which was released mainly in the bath. (Remarkably, there was no ${ }^{14} \mathrm{C}$-glutamine synthesized in these experiments, indicating that glutamine synthetase is not active in these glial cells.) This is consistent with a sustained uptake and metabolism of glutamate by glia. The accumulation of [U- $\left.{ }^{14} \mathrm{C}\right]$ glutamate was strongly $\mathrm{Na}^{+}$-dependent in accordance with the $\mathrm{Na}^{+}$dependence of the NAD(P)H response (Fig. 2b,f).

\section{The metabolic effect of glutamate in glia is not directly $\mathbf{p H}$-dependent}

In vertebrate retinal glial cells, exposure to glutamate causes a transient acidosis, probably because the glutamate uptake carrier countertransports $\mathrm{pH}$-changing anions $\left(\mathrm{OH}^{-}\right.$or $\left.\mathrm{HCO}_{3}^{-}\right)$(Bouvier et al., 1992). Because both mitochondria and carbonic anhydrase are absent in honeybee glial cells (Tsacopoulos et al., 1987; Walz, 1988), this countertransport is expected to be limited to $\mathrm{OH}^{-}$ when these cells are isolated. We show that the glutamate-induced acidosis was mild (Fig. 2e), in comparison with that recorded in vertebrate cells (Bouvier et al., 1992). Aspartate, which uses the same transport carrier as glutamate (Christensen, 1990; Bouvier et al., 1992), caused a mild, transient acidosis of similar amplitude to that induced by glutamate (Fig. $2 e$ ) but smaller than that caused by the weak acid citrate (Fig. 1e). In sharp contrast to glutamate, however, aspartate (Fig. 2a,d) and citrate (Fig. 1d) did not induce significant $\mathrm{NAD}(\mathrm{P}) \mathrm{H}$ fluorescence increases. It seems, therefore, that the glutamate-induced increase in $\mathrm{NAD}(\mathrm{P}) \mathrm{H}$ is attributable to a direct effect on a specific intracellular enzymatic target, probably cytosolic GDH (Veuthey et al., 1994), and not through intracellular $\mathrm{pH}$ changes as suggested before (Bouvier et al., 1992). 


\section{Biochemical evidence of the metabolic effects of $\mathrm{NH}_{4}{ }^{+}$ and glutamate in glia}

In honeybee glial cells, where pyruvate is not reduced to lactate (Tsacopoulos et al., 1987), GDH works in tandem with alanine aminotransferase (ALAT; L-alanine:2-oxoglutarate aminotransferase; EC 2.6.1.2) to produce alanine and $\mathrm{NAD}(\mathrm{P})^{+}$(Fahien et al., 1971; Tsacopoulos et al., 1994; Veuthey et al., 1994; Tsacopoulos and Magistretti, 1996). The concentration of pyruvate in these cells is low (below $0.2 \mathrm{~mm}$ ). Consequently, the rate of alanine synthesis should be controlled by the rate of glycolytic production of pyruvate and the supply from the extracellular space of glutamate at noninhibitory levels for GDH (Fahien et al., 1971). We provide biochemical support to this hypothesis: exposing glial cells to a mixture of $1 \mathrm{mM} \mathrm{NH}_{4}{ }^{+}$and $1 \mathrm{~mm}$ glutamate induced a large increase in the biosynthesis of alanine (Fig. $3 a$ ). Most significantly, the amount of alanine released into the bath under these conditions increased fivefold as compared with controls, i.e., with no glutamate and no $\mathrm{NH}_{4}{ }^{+}$added to the bath (Fig. $3 a$, right). The effect of $\mathrm{NH}_{4}{ }^{+}$alone was significant but was less important than when combined with glutamate (Fig. 3a). We further asked whether alanine is also produced from glycogen stores. Radiolabeled [U- $\left.{ }^{14} \mathrm{C}\right]$ glucose therefore was added to the glial bath and thereby competed with glycogen pools as the substrate for alanine formation (Fig. 3b). The specific activity calculated for intracellular alanine was very small at two different concentrations of $\left[\mathrm{U}-{ }^{14} \mathrm{C}\right]$ glucose, consistent with the idea that the substrate for its formation is mostly glycogen. The specific activity of alanine in the bath, however, was $>10$-fold higher than inside the cells (Fig. $3 b$, bottom panels), indicating that alanine is produced from both exogenous $\left[\mathrm{U}^{14}{ }^{14} \mathrm{C}\right]$ glucose and glycogen but that alanine produced from exogenous glucose is released more rapidly into the bath (Poitry-Yamate et al., 1995). The addition of 1 mM $\mathrm{NH}_{4}{ }^{+}$and $1 \mathrm{~mm}$ glutamate caused as much as a fivefold decrease in the specific activity of alanine in the bath, whereas that inside the cells increased further (Fig. 3b, bottom panels). This is probably the consequence of a massive hydrolysis of glycogen caused by the pulling effect of increased glycolysis (EvêquozMercier and Tsacopoulos, 1991). This mechanism is similar to that operating in mammalian astrocytes, both fresh and cultured, with respect to glutamate signaling and lactate formation and release (Parpura et al., 1994; Pellerin and Magistretti, 1994; Poitry-Yamate et al., 1995; Tsacopoulos and Magistretti, 1996).

\section{DISCUSSION}

We have explored the signal(s) by which neurons communicate to glia their need for energy substrate and at what level the signals exert their metabolic effect in glia. The experimental evidence presented in this paper shows that ammonium and glutamate released physiologically by neurons inform glial cells to increase their production and release of energy substrate.

Baseline levels of ammonia in honeybee retinal slices or homogenates are higher than in mammalian brain (Cooper and Plum, 1987). However, as we have shown, the major part of ammonia is found in the mitochondria, and this may be related to the consumption of proline in this tissue. Although it is difficult to estimate the cytosolic and extracellular levels of ammonia in the intact retina, it is quite likely that they are much less than the values reported in Figure $1 a$.

The model diagram based on our findings (Fig. 4) describes a novel way by which this arises. Ammonium and glutamate exert their signaling effect intracellularly and synchronously on three enzymatic reactions in the glia: during activation, $\mathrm{NH}_{4}{ }^{+}$and

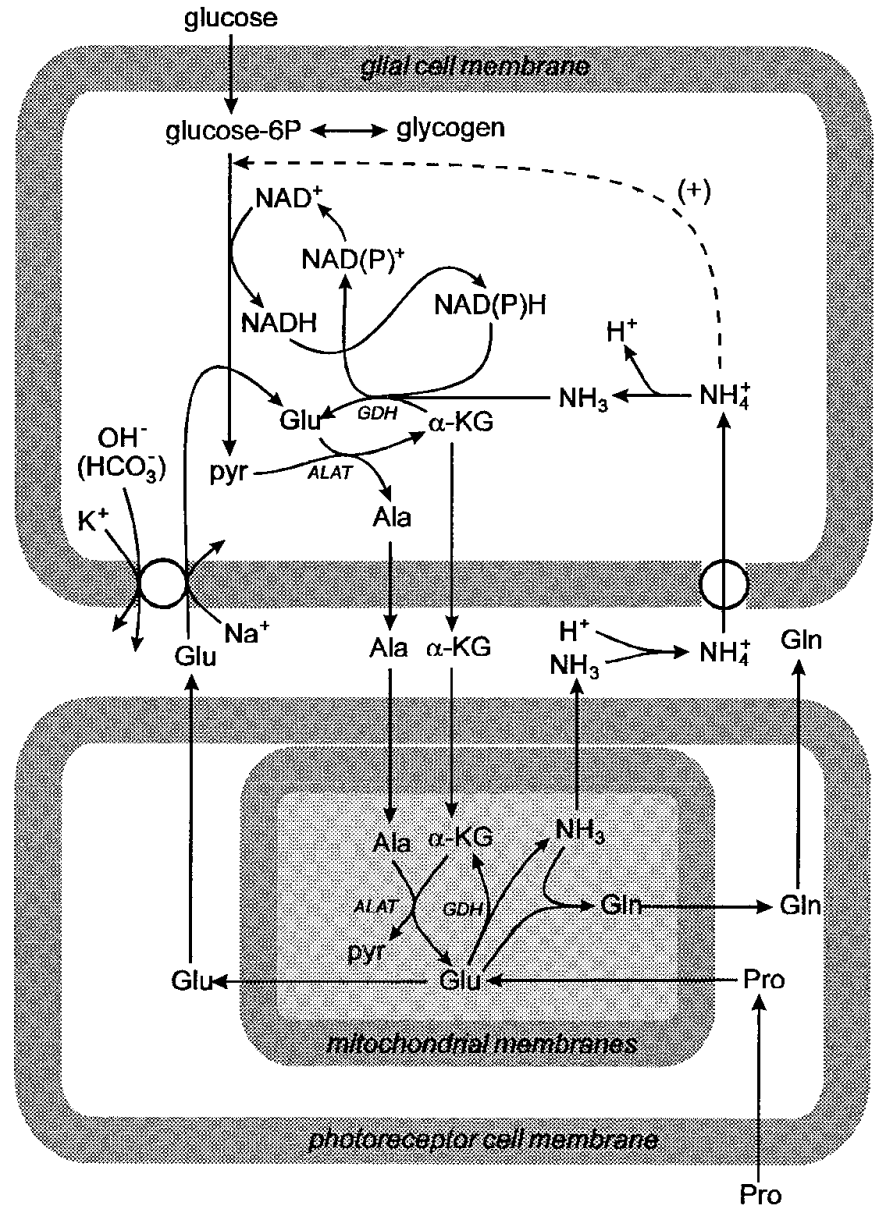

Figure 4. Model diagram of nitrogen and carbon metabolism in the honeybee retina showing the biochemical pathways involved in the trafficking of metabolites between glial cells and photoreceptors and showing how $\mathrm{NH}_{3} / \mathrm{NH}_{4}{ }^{+}$and glutamate may regulate glial metabolism. Glucose is metabolized by glial cells to alanine, which is, in turn, transferred to photoreceptors to fuel oxidative metabolism; the amino group carried by alanine leaves the photoreceptors as $\mathrm{NH}_{3}$ and returns to glial cells as $\mathrm{NH}_{4}{ }^{+}$, which enters the cells through a transport system similar to that found in kidney cells. Proline, the second substrate for oxidative metabolism of photoreceptors, enters mitochondria, where it is converted to glutamate and to glutamine. Both are released by photoreceptors; glutamate enters glial cells via a $\mathrm{Na}^{+}$-dependent carrier. For the return loop to photoreceptors, the glutamate carbon then leaves the glia as $\alpha$-ketoglutarate and glutamate $\mathrm{N}$ as alanine, as discussed by Yudkoff et al. (1986) for mammalian CNS. Nitrogen in excess can leave the retina either as $\mathrm{NH}_{3} / \mathrm{NH}_{4}{ }^{+}$or glutamine. $\alpha-K G, \alpha$-Ketoglutarate; Ala, alanine; $A L A T$, alanine aminotransferase; $G D H$, glutamate dehydrogenase; Glu, glutamate; Gln, glutamine; Pro, proline; pyr, pyruvate.

glutamate operating at two sites (PFK and ALAT) accelerate the production of alanine from pyruvate and of $\alpha$-ketoglutarate from glutamate. Alanine and $\alpha$-ketoglutarate are taken up by neurons and contribute there to the homeostasis of the mitochondrial redox potential (Tsacopoulos et al., 1994). At the same time $\mathrm{NH}_{4}{ }^{+}$and glutamate have antagonistic effects at a third site (GDH). Thus, the overall effect of $\mathrm{NH}_{4}{ }^{+}$on glial metabolism is to increase the production of alanine, and that of glutamate is to adjust this production to the metabolic needs of photoreceptors. In intact tissue, the operation of this fine control during neuronal activity probably would result in smaller and faster $\Delta \mathrm{NAD}(\mathrm{P}) \mathrm{H}$ than those recorded in isolated cells, and the flux through GDH in glia might be expected to rise and fall with shifts of internal 
concentrations of glutamate and/or $\mathrm{NH}_{4}{ }^{+}$. This signaling depends on functional plasma membrane transport systems for $\mathrm{NH}_{4}{ }^{+}$and glutamate in glial cells and leads to the transformation of these molecules intracellularly. In metabolically active glial cells containing enough glycogen or in the presence of extracellular glucose, $\mathrm{NH}_{4}{ }^{+}$and glutamate taken up from the extracellular space do not accumulate intracellularly in excess, because they are transformed continuously to alanine and $\alpha$-ketoglutarate, respectively. It is conceivable, however, that in some pathological condition the metabolism of glial cells is impaired, leading to the accumulation of $\mathrm{NH}_{4}{ }^{+}$and glutamate and therefore to swelling in glia (Albrecht et al., 1994). This would lead to a deficient fuelling of neurons and possibly contribute to neuronal death.

This tight regulation of metabolic coupling between neurons and glial cells by means of chemical signals turns the nourishing of neurons by glia into a function, instead of a passive process, as it is widely considered (see Pfrieger and Barres, 1995). It is tempting to extrapolate some elements of the model presented in Figure 4 to the vertebrate nervous system, even if differences seem to exist. The $\mathrm{Na}^{+}$dependence of glutamate uptake in glial cells, notably studied in salamander Müller glial cells, shares similar properties to that in the honeybee glial cells. The glutamate-induced increase in $\mathrm{NAD}(\mathrm{P}) \mathrm{H}$ fluorescence described here also was found in salamander Müller cells, initially under somewhat artificial conditions of voltage clamp (Barbour et al., 1993) and more recently in intact, acutely isolated Müller cells. Fluorescence image analysis revealed that this increase occurs in all parts of the cell, including the mitochondria-free end feet (Uga and Smelser, 1973), thus suggesting a glutamate-induced increase in glycolytic NADH (Tsacopoulos and MacLeish, 1996).

Astroglial energy metabolism is stimulated by increased $\mathrm{Na}^{+}$ entry, probably via a specific activation of the $\mathrm{Na}^{+}$pump (Takahashi et al., 1995). Because glutamate in astroglia is cotransported with $\mathrm{Na}^{+}$, this would lead to an increased $\left[\mathrm{Na}^{+}\right]_{\mathrm{i}}$ and stimulation of glucose metabolism. Recent results of Pellerin and Magistretti (1994) are in accordance with this prediction. The activation of the pump is, however, an unlikely explanation for the metabolic effect of glutamate described in acutely isolated retinal glial cells, because aspartate uses the same transporter as glutamate (Christensen, 1990) but, in contrast to glutamate, does not induce an increase in $\mathrm{NAD}(\mathrm{P}) \mathrm{H}$ either in honeybee glial cells (see Results) or in salamander Müller cells (Bouvier et al., 1992). Honeybee glial cells play a crucial role in the positioning of sodium pumps on the plasma membrane of the photoreceptor and in retaining the pumps at the contact sites. They have, however, very few pumping sites on their own membranes (Baumann and Takeyasu, 1993). Indeed, pumping $\mathrm{Na}^{+}$is not a crucial mechanism for spatial buffering of $\mathrm{K}^{+}$by glia during neuronal stimulation in both the insect and vertebrate retina (Coles, 1989).

Apparently, the fixation of ammonia occurs differently in honeybee glial cells and astrocytes. In vertebrate nervous tissue, glutamine synthetase is localized predominantly within astrocytes (Norenberg and Martinez-Hernandez, 1979) and in Müller glial cells (Riepe and Norenberg, 1977), suggesting a predominant formation of glutamine there. Recently, Waniewski (1992) found that ammonium at near-physiological concentrations $(\sim 100 \mu \mathrm{M})$ more than doubles the rate of glutamate to glutamine transformation in astrocyte cultures. This was evidence that the metabolism of glutamate to glutamine in astrocytes depends on extracellular ammonia. However, so that ammonia might be established as a metabolic signal in astrocytes, it is necessary to demonstrate that neuronal activity induces an increase of $\mathrm{NH}_{4}{ }^{+}$production that does not lead to saturation of the glutamate synthetase reaction occurring in astrocytes $\left(K_{\mathrm{m}}\right.$ for $\mathrm{NH}_{4}{ }^{+}$is $\sim 0.18 \mathrm{mM}$; Palmiljans et al., 1962). Contrary to astrocytes, the acutely isolated honeybee glial cells do not synthesize glutamine but, instead, aminate pyruvate to alanine. Glutamine found in this retina probably is formed in the mitochondria of photoreceptors, a compartment in which the availability of ATP is likely to be higher than in the mitochondria-poor glial cells. This assumption is compatible with the finding in superfused slices of intact honeybee retina that ${ }^{15} \mathrm{~N}$-glutamine is formed from ${ }^{15} \mathrm{~N}$-proline, a substrate known to be consumed predominantly in the mitochondria of photoreceptors (Tsacopoulos et al., 1994, 1997). In any case, if there is a glutamate-glutamine cycle (see discussion by Yudkoff et al., 1992), nitrogen fixed on glutamine ultimately must return to astrocytes so that synthesis of amino acids can continue. Cultured astrocytes exposed to $\mathrm{NH}_{4} \mathrm{Cl}$ for $4 \mathrm{~d}$ swell (Norenberg et al., 1991), possibly indicating the existence of some unidirectional $\mathrm{NH}_{4}{ }^{+}$transport system similar to the one we found in the honeybee glial cells.

Glutamate signaling between cortical astrocytes and neurons was shown recently to occur in mammalian cell culture (Parpura et al., 1994). However, the signaling that we have described in the present paper goes further, confirming the function of glial cells in nourishing and maintaining nervous tissue.

\section{REFERENCES}

Albrecht J, Bender AS, Norenberg MD (1994) Ammonia stimulates the release of taurine from cultured astrocytes. Brain Res 660:288-292.

Amlal H, Paillard M, Bichara M (1994) $\mathrm{NH}_{4}{ }^{+}$transport pathways in cells of medullary thick ascending limb of rat kidney. $\mathrm{NH}_{4}{ }^{+}$conductance and $\mathrm{K}^{+} / \mathrm{NH}_{4}{ }^{+}\left(\mathrm{H}^{+}\right)$antiport. J Biol Chem 269:21962-21971.

Barbour B, Magnus C, Szatkowski M, Gray PTA, Attwell D (1993) Changes in $\mathrm{NAD}(\mathrm{P}) \mathrm{H}$ fluorescence and membrane current produced by glutamate uptake into salamander Müller cells. J Physiol (Lond) 466:573-597.

Baumann O, Takeyasu K (1993) Polarized distribution of Na, K-ATPase in honeybee photoreceptors is maintained by interaction with glial cells. J Cell Sci 105:287-301.

Bouvier M, Szatkowski M, Amato A, Attwell D (1992) The glial cell glutamate uptake carrier countertransports $\mathrm{pH}$-changing anions. Nature 360:471-474.

Brew H, Attwell D (1987) Electrogenic glutamate uptake is a major current carrier in the membrane of axolotl retinal glial cells. Nature 327:707-709.

Cardinaud B, Coles JA, Perrottet P, Spencer AJ, Osborne MP, Tsacopoulos M (1994) The composition of the interstitial fluid in the retina of the honeybee drone: implications for the supply of substrates of energy metabolism from blood to neurons. Proc R Soc Lond [Biol] 257:49-58.

Christensen HN (1990) Role of amino acid transport and countertransport in nutrition and metabolism. Physiol Rev 70:43-77.

Coles JA (1989) Functions of glial cells in the retina of the honeybee drone. Glia 2:1-9.

Coles JA, Marcaggi P, Vega C, Cotillon N (1996a) Effects of photoreceptor metabolism on interstitial and glial cell $\mathrm{pH}$ in bee retina: evidence of a role for $\mathrm{NH}_{4}{ }^{+}$. J Physiol (Lond) 495:305-318.

Coles JA, Thwaites DT, Marcaggi P, Deitmer JW (1996b) Ammonium causes acidification of glial cells isolated from drone retina. J Physiol (Lond) 491:147P

Cooper AJL, Plum F (1987) Biochemistry and physiology of brain ammonia. Physiol Rev 67:440-519.

Evêquoz-Mercier V, Tsacopoulos M (1991) The light-induced increase of carbohydrate metabolism in glial cells of the honeybee retina is not mediated by $\mathrm{K}^{+}$movement nor by cAMP. J Gen Physiol 98:497-515.

Fahien LA, Lin-Yu J-H, Smith SE, Happy JM (1971) Interactions between glutamate dehydrogenase, transaminases, and keto acids. J Biol Chem 246:7241-7249.

Hawkins RA, Miller AL, Nielsen RC, Veech RL (1973) The acute action of ammonia on rat brain metabolism in vivo. Biochem J 134:1001-1008. 
Innocent C (1995) Immobilisation de biomolécules dans des polypyrroles fonctionnalisés: application à l'électroanalyse. $\mathrm{PhD}$ dissertation, Université Joseph Fourier, Grenoble, France.

Kanai Y, Hediger MA (1992) Primary structure and functional characterization of a high-affinity glutamate transporter. Nature 360:467-471.

Kikeri D, Sun A, Zeidel ML, Hebert SC (1989) Cell membranes impermeable to $\mathrm{NH}_{3}$. Nature 339:478-480.

Kinne R, Kinne-Saffran E, Schütz H, Schölermann B (1986) Ammonium transport in medullary thick ascending limb of rabbit kidney: involvement of the $\mathrm{Na}^{+}, \mathrm{K}^{+}, \mathrm{Cl}^{-}$-cotransporter. J Membr Biol 94:279-284.

Larrabee MG (1983) Lactate uptake and release in the presence of glucose by sympathetic ganglia of chicken embryos and by neuronal and nonneuronal cultures prepared from these ganglia. J Neurochem 40:1237-1250.

Lowry OH, Passonneau JV (1966) Kinetic evidence for multiple binding sites on phosphofructokinase. J Biol Chem 241:2268-2279.

Norenberg MD, Martinez-Hernandez A (1979) Fine structural localization of glutamine synthetase in astrocytes of rat brain. Brain Res 161:303-310.

Norenberg MD, Baker L, Norenberg LO, Blicharska J, Bruce-Gregorios JH, Neary JT (1991) Ammonia-induced astrocyte swelling in primary culture. Neurochem Res 16:833-836.

Palmiljans V, Krishnaswamy PR, Dumville G, Meister A (1962) Studies on the mechanism of glutamine synthesis: isolation and properties of the enzyme from sheep brain. Biochemistry 1:153-158.

Parpura V, Basarsky TA, Liu F, Jeftinija K, Jeftinija S, Haydon PG (1994) Glutamate-mediated astrocyte-neuron signalling. Nature 369:744-747.

Pellerin L, Magistretti PJ (1994) Glutamate uptake into astrocytes stimulates aerobic glycolysis: a mechanism coupling neuronal activity to glucose utilization. Proc Natl Acad Sci USA 91:10625-10629.

Pfrieger FW, Barres BA (1995) What the fly's glia tell the fly's brain. Cell 83:671-674.

Poitry-Yamate CL, Poitry S, Tsacopoulos M (1995) Lactate released by Müller glial cells is metabolized by photoreceptors from mammalian retina. J Neurosci 15:5179-5191.

Riepe RE, Norenberg MD (1977) Müller cell localisation of glutamine synthetase in rat retina. Nature 268:645-655.

Takahashi S, Driscoll BF, Law MJ, Sokoloff L (1995) Role of sodium and potassium ions in regulation of glucose metabolism in cultured astroglia. Proc Natl Acad Sci USA 92:4616-4620.

Tsacopoulos M, MacLeish PR (1996) The possible role of glutamate as a metabolic signal trafficking between neurons and Müller cells. J Brain Res 37:229.

Tsacopoulos M, Magistretti PJ (1996) Metabolic coupling between glia and neurons. J Neurosci 16:877-885.

Tsacopoulos M, Poitry S (1995) Metabolite exchanges and signal trafficking between glial cells and neurons in the insect retina. In: Neuron-glia interrelations during phylogeny. II. Plasticity and regeneration (Vernadakis A, Roots B, eds), pp 79-93. Totowa, NJ: Humana.

Tsacopoulos M, Coles JA, Van De Werve G (1987) The supply of metabolic substrate from glia to photoreceptors in the retina of the honeybee drone. J Physiol (Paris) 82:279-287.

Tsacopoulos M, Veuthey AL, Saravelos SG, Perrottet P, Tsoupras G (1994) Glial cells transform glucose to alanine, which fuels the neurons in the honeybee retina. J Neurosci 14:1339-1351.

Tsacopoulos M, Poitry-Yamate CL, Poitry S, Perrottet P, Veuthey A-L (1997) The nutritive function of glia is regulated by signals released by neurons. Glia, in press.

Uga S, Smelser GK (1973) Comparative study of the fine structure of retinal Müller cells in various vertebrates. Invest Ophthalmol Vis Sci 12:434-448.

Veuthey A-L, Tsacopoulos M, Millan-de-Ruiz L, Perrottet P (1994) Cellular and subcellular localization of hexokinase, glutamate dehydrogenase, and alanine aminotransferase in the honeybee drone retina. J Neurochem 62:1939-1946.

Walz B (1988) Brain but not retinal glial cells have carbonic anhydrase activity in the honeybee drone. Neurosci Lett 85:47-50.

Waniewski RA (1992) Physiological levels of ammonia regulate glutamine synthesis from extracellular glutamate in astrocyte cultures. J Neurochem 58:167-174.

Yudkoff M, Nissim I, Hummeler K, Medow M, Pleasure D (1986) Utilization of $\left[{ }^{15} \mathrm{~N}\right]$ glutamate by cultured astrocytes. Biochem $\mathrm{J}$ 234:185-192.

Yudkoff M, Nissim I, Hertz L, Pleasure D, Erecinska M (1992) Nitrogen metabolism: neuronal-astroglial relationships. Prog Brain Res 94:213-224. 